\title{
Hydroacoustical evidence of autumn inshore residence of the pelagic red crab Pleuroncodes planipes at Punta Eugenia, Baja California, Mexico
}

\author{
Jaime Gómez-Gutiérrez ${ }^{1, *}$, Edgar Domínguez-Hernández ${ }^{2}$, Carlos J. Robinson², Virgilio Arenas ${ }^{2}$ \\ ${ }^{1}$ Departamento de Plancton y Ecología Marina, Centro Interdisciplinario de Ciencias Marinas, Apartado Postal 592, CP 23000 La Paz, \\ Baja California Sur, Mexico \\ ${ }^{2}$ Laboratorio de Ecología de Pesquerías, Instituto de Ciencias del Mar y Limnología UNAM, Apartado Postal 70-305, CP 04510, \\ Ciudad de Mexico, DF, Mexico
}

\begin{abstract}
A previously published conceptual model of the life history of the red crab Pleuroncodes planipes (Galatheidae) (Stimpson, 1860) reports that the center of distribution of this micronektonic crustacean is located at Bahía Magdalena, on the southwest coast of Baja California (25 to $24^{\circ} 20^{\prime} \mathrm{N}$ ). During spring, the highest abundance of mature females is found nearshore with abundance peaks of larval stages during February and March. Larval drift offshore is associated with a strong Ekman transport system, and the virtual disappearance of the adult pelagic and benthic population from the neritic region at Bahía Magdalena in late summer and autumn can be explained by an inshore-offshore migration. However, huge benthic-pelagic concentrations of this crustacean occur nearshore during autumn at Punta Eugenia (27 to $29^{\circ} \mathrm{N}$ ). Circadian cycles of the spatial distribution of these aggregations were recorded with a single beam echosounder Simrad EY-200 (200 kHz) along Baja California during October 1994, March, June, and October 1995, and March and June 1996. Data obtained from Isaacs-Kidd midwater net trawls during October 1994 along Baja California were used to identify the red crab aggregations using hydroacoustics. The target strength of the red crab ranged between -50 and $-54 \mathrm{~dB}$. The largest aggregations were found in Bahía Magdalena during summer (June 1995 and 1996; 24 to $25^{\circ} \mathrm{N}$ ) and nearshore at Punta Eugenia $\left(27\right.$ to $\left.28^{\circ} \mathrm{N}\right)$ during autumn and spring (March 1995 and 1996, October 1994 and 1995). These observations suggest that the conceptual model of inshoreoffshore adult population migration is valid for Bahía Magdalena, but apparently not for Punta Eugenia at least during autumn. At Punta Eugenia an abrupt change in the orientation of the shoreline enhances upwelling events and promotes semipermanent eddies, thus supporting the inshore residence of this adaptive omnivorous-detritivorous crustacean.
\end{abstract}

KEY WORDS: Hydroacoustic · Pleuroncodes planipes . Inshore-offshore distribution · Baja California

Resale or republication not permitted without written consent of the publisher
The red crab Pleuroncodes planipes (Stimpson, 1860) dominates the micronektonic fauna in the nearshore waters of the Pacific coast of Baja California, Mexico, and is a dominant functional component of the upwelling ecosystem in the California Current (Smith et al. 1975). Dense adult surface swarms have been found inshore during the first half of the year in coastal upwelling regions near Bahía Magdalena $\left(24^{\circ} \mathrm{N}\right)$ (Fig. 1), and they migrate offshore during the second half of the year (Aurioles-Gamboa 1992, 1995, Aurioles-Gamboa et al. 1994). This seasonal inshore-offshore model of adult distribution is coupled to an offshore passive larval drift of the zoeal and postlarval stages from Bahía Magdalena after the peak of reproductive activity in February-March. This larval drift of the red crab is promoted by surface Ekman transport, indicated by positive upwelling indices (Gómez-Gutiérrez \& Sánchez-Ortíz 1997). The California Current carries the early postlarval stages far to the southwest, up to $130^{\circ} \mathrm{W}$. Ovigerous females have been reported in the open ocean, but their contribution to the overall population reproduction is small in comparison to that from the coastal areas (Boyd 1967, Longhurst \& Seibert 1971). Several studies indicate how a semipermanent eddy, which develops in autumn near Punta Eugenia (Fig. 1), causes nearshore retention of several ichthyoplanktonic species (Hewitt 1981) and holoplanktonic

\footnotetext{
*Present address: College of Oceanic and Atmospheric Sciences, Oregon State University, 104 Oceanography Administration Building, Corvallis, Oregon 97331-5503, USA. E-mail: jgomezgu@oce.orst.edu
} 


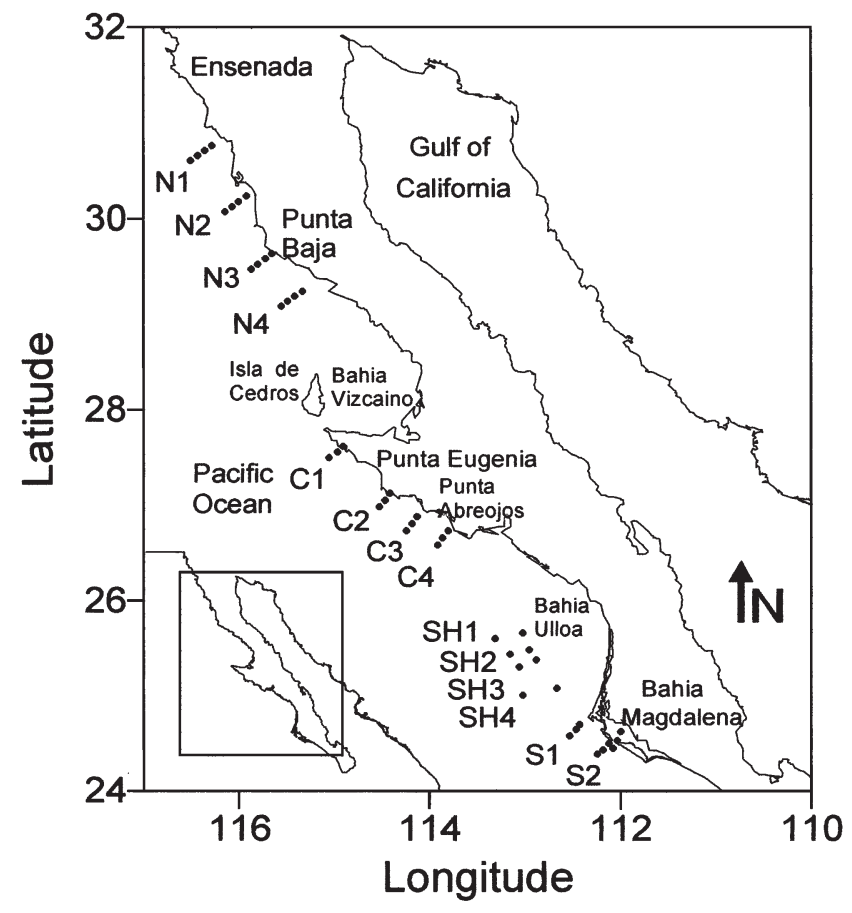

Fig. 1. Map of study area, indicating sampling stations covered during October 1994 to June 1996. Oceanographic transects $\mathrm{N} 1$ to $\mathrm{N} 4$ are northern region $\left(29\right.$ to $\left.31^{\circ} \mathrm{N}\right), \mathrm{C} 1$ to $\mathrm{C} 4$ are center region $\left(29\right.$ to $\left.31^{\circ} \mathrm{N}\right), \mathrm{SH} 1$ to $\mathrm{SH} 4$ are the shallow area in

Bahía Ulloa, and $\mathrm{S} 1$ to $\mathrm{S} 4$ are southern region $\left(24^{\circ} \mathrm{N}\right)$

species, such as euphausiids (Lavaniegos 1994). Several nektonic species, such as the adult anchovy Engraulis mordax, fail to show a clear distribution pattern related to eddies in this region, but make daily migrations from the continental shelf to oceanic waters (Robinson et al. 1995). Since the red crab has a reduced swimming ability, its distribution is strongly affected by eddies, jet streams, or horizontal advective transport. Every 6 to $10 \mathrm{yr}$, warm southern currents associated with El Niño-Southern Oscillation events (ENSO) distribute these crustaceans as far north as the California coast (Smith 1985). Many are stranded on the shore by wind, waves, and currents. In Baja California, particularly at Bahía Magdalena, their bodies have been known to form windrows up to $1 \mathrm{~m}$ deep every year (Aurioles-Gamboa et al. 1994).

The distribution and abundance of the red crab has been recently studied using commercial shrimp-net catches along the Pacific coast of Baja California (Aurioles-Gamboa 1992, 1995). During the cold season (winter and spring), when the species breeds, the distribution area in the south was about $13 \times 10^{3} \mathrm{~km}^{2}$, with a standing stock of $320000 \mathrm{t}$, whereas in the northern region the area used by the crustacean was about $5.5 \times$ $10^{3} \mathrm{~km}^{2}$ with a standing stock of $140000 \mathrm{t}$. During the warm season (summer and autumn), when the red crab migrates offshore, both the distribution area and standing stock in the south were reduced to $7.2 \times 10^{3}$ $\mathrm{km}^{2}$ and $2000 \mathrm{t}$. In the northern region, an even smaller distribution area and abundance were recorded, about $2.9 \times 10^{3} \mathrm{~km}^{2}$ and $88000 \mathrm{t}$ (Aurioles-Gamboa 1992, 1995).

Hydroacoustics have been used since the early 1970 s in Mexican waters to estimate the distribution, abundance, and size-frequency distribution of the red crab. The first attempt to understand the vertical distribution of the pelagic phase of the red crab was made using a low frequency echosounder in a coastal upwelling area off Baja California (Blackburn \& Thorne 1974). This and subsequent hydroacoustic studies were conducted in relatively small areas (see Arvizu et al. 1974, Blackburn 1977, Walsh et al. 1977, Okonski \& Martini 1978). Recent observations of diel vertical migration of the red crab along the west coast of Baja California have shown that vertical migration in this species can take place in a very short period (<60 min) (Robinson \& Gómez-Gutiérrez 1998). However, no extensive hydroacoustical monitoring of the red crab has been attempted in most of its distribution area. Therefore, the goal of this study was to do comprehensive hydroacoustical monitoring of Pleuroncodes planipes aggregations along the west coast of Baja California during several seasons. Sampling effort was focused on autumn, when according to previous studies most of the juvenile and adult population should be distributed oceanward of the continental shelf. We designed a sampling strategy to detect changes on a circadian time scale along the Baja California peninsula.

Materials and methods. Biological, oceanographic and hydroacoustical data were collected along the west coast of Baja California, Mexico, from 17 to 30 October 1994 on the RV 'El Puma'. Transects perpendicular to the coast and $18 \mathrm{~km}$ long were sampled from 3 different areas, from Ensenada to Punta Baja (north); from Punta Eugenia to Punta Abreojos (center); and near Bahía Magdalena and a shallow zone (SH) located northwest of this bay (south). All transects covered the neritic, slope and oceanic zones with approximately equal lengths (ca $6 \mathrm{~km}$ ). The continental shelf at Punta Eugenia is very narrow and depths greater than $2000 \mathrm{~m}$ are found relatively close to the coast resembling oceanic conditions. Oceanographic stations were located at both ends and in the middle point (slope) of each transect (Fig. 1). Each transect was monitored for approximately $24 \mathrm{~h}$, repeating a circle 6 times that started from the neritic station, headed toward the oceanic station and returned to the neritic station about $4 \mathrm{~h}$ later. The ship speed was on average 10 knots. Temperature $\left({ }^{\circ} \mathrm{C}\right)$ and salinity were recorded at each oceanographic station (0 to $200 \mathrm{~m}$ ) using a CTD Inter-Ocean S4. A modified Isaacs-Kidd midwater net 
trawl (cod-end liner of $500 \mu \mathrm{m}$ mesh and $2.5 \times 2.5 \mathrm{~m}$ mouth area) was towed approximately 20 to $30 \mathrm{~min}$ (4 to 6 knots) between stations, at depths where acoustics show echoes related to red crab concentrations. Adults were identified by sex. The carapace length (CL) of juveniles and adults was measured from the base of subrostral spines of the rostrum to the posterior midpoint of the carapace. Wet weight of red crabs caught with the Isaacs-Kidd net was estimated from size data for males and females separately, using regression equations reported by Gómez-Gutiérrez \& SánchezOrtíz (1997).

After this pilot survey during October 1994 to identify the target strength of the red crab aggregations, hydroacoustical information was obtained during 5 additional oceanographic surveys carried out during March, June, and October 1995 and March and June 1996 in the region of Punta Eugenia and Bahía Magdalena. Hydroacoustical data in all the oceanographic surveys were collected using a Simrad EY-200, singlebeam echosounder, $200 \mathrm{kHz}$, with a nominal beam width of $7^{\circ}$. The transducer depth was $4 \mathrm{~m}$ and the echo analysis started $1 \mathrm{~m}$ from the transducer (i.e. $5 \mathrm{~m}$ below the surface). The unit was calibrated with a $13.7 \mathrm{~mm}$ copper sphere $(-45 \mathrm{~dB})$. Ping rate was 1.7 pings $\mathrm{s}^{-1}$ and the minimum threshold noise level was $400 \mathrm{mV}$. For analysis, we used a Hydroacoustic Data Acquisition System (HADAS, ver. 4.01) (Lindem $\&$ Houri 1988). This is an echo-counting method that transforms the received echo distribution into area densities and hence estimates abundance expressed as ind. $\mathrm{ha}^{-1}$. The system is based on a combination of computer hardware and software that allows hydroacoustic data to be digitized and stored. To calculate target strength, HADAS uses a modification of the Craig \& Forbes (1969) algorithm to remove the beam pattern effect. Pulse duration was set at $0.3 \mathrm{~ms}$ and pulse length was $45 \mathrm{~cm}$. Accordingly, to resolve separate individuals, targets must differ in range by at least $22.5 \mathrm{~cm}$ (MacLennan \& Simmonds 1992). Considering that we monitored only in the open sea, this range allows the use of a time-varied gain $40 \log R$ for echo counting and target-size distributions (MacLennan \& Simmonds 1992) for most of the red crab aggregations. Only in a few cases, where the red crabs were extremely aggregated, is the estimation using echocounting technique misleading and any attempt to estimate the hydroacoustic abundance could be considered as an underestimation. For this reason, these cases were excluded from the analysis (about $5 \%$ of all the echograms analyzed). Hydroacoustic data are usually not normally distributed due to the natural patchiness of pelagic organisms; therefore non-parametric statistical tests were used to test differences in the abundance between different latitudinal regions.

Results. Strong latitudinal changes in the environmental conditions were evident along the west coast of Baja California during October 1994. Oceanographic features of the water column from 3 typical transects (north, center, and south) are shown in Table 1. The

Table 1. Sea surface temperature (SST), temperature at 10 and $50 \mathrm{~m}$, thermocline depth with a mixed surface layer and halocline depth of the water column from 3 typical transects (north, center, and south) along the west coast of Baja California during October $1994 .{ }^{\mathrm{D}}=$ day, ${ }^{\mathrm{N}}=$ night. $\mathrm{N}=$ north, $\mathrm{C}=$ center, and $\mathrm{S}=$ south; number indicates the transect within the region. The position of the stations are also indicated as neritic $<200 \mathrm{~m}$, slope $\sim 200 \mathrm{~m}$, and oceanic $>300 \mathrm{~m}$

\begin{tabular}{|c|c|c|c|c|c|c|}
\hline Station and location & $\operatorname{SST}\left({ }^{\circ} \mathrm{C}\right)$ & $\begin{array}{c}\text { Temperature }\left({ }^{\circ} \mathrm{C}\right) \\
\text { at } 10 \mathrm{~m}\end{array}$ & $\begin{array}{c}\text { Temperature }\left({ }^{\circ} \mathrm{C}\right) \\
\text { at } 50 \mathrm{~m}\end{array}$ & $\begin{array}{c}\text { Thermocline } \\
\text { depth (m) }\end{array}$ & $\begin{array}{c}\text { Depth of mixed } \\
\text { surface layer }(\mathrm{m})\end{array}$ & $\begin{array}{l}\text { Halocline } \\
\text { depth }(\mathrm{m})\end{array}$ \\
\hline D N3 Neritic & 16.1 & 15.8 & 13.6 & 17 & 6 & 27 \\
\hline D N3 Slope & 15.6 & 16.7 & 13.4 & 23 & 32 & 107 \\
\hline D N3 Oceanic & 18.3 & 18.3 & 14.0 & 18 & 23 & 73 \\
\hline${ }^{N}$ N3 Neritic & 16.2 & 16.2 & 13.6 & 17 & 20 & 27 \\
\hline N N3 Slope & 16.3 & 16.3 & 13.2 & 47 & 19 & 87 \\
\hline${ }^{\mathrm{N}} \mathrm{N} 3$ Oceanic & 18.0 & 18.0 & 13.5 & 17 & 23 & 127 \\
\hline${ }^{\mathrm{N}} \mathrm{C} 4$ Neritic & 19.8 & 19.8 & 16.7 & 42 & 20 & 52 \\
\hline${ }^{N}$ C4 Slope & 20.0 & 20.1 & 15.1 & 37 & 23 & 67 \\
\hline${ }^{\mathrm{N}} \mathrm{C} 4$ Oceanic & 20.3 & 20.3 & 14.1 & 22 & 22 & 72 \\
\hline${ }^{\mathrm{D}} \mathrm{C} 4$ Neritic & 20.5 & 19.7 & 16.4 & 22 & 22 & 72 \\
\hline${ }^{\mathrm{D}}$ C4 Slope & 20.1 & 20.2 & 15.4 & 33 & 26 & 67 \\
\hline D C4 Oceanic & 20.3 & 20.3 & 14.1 & 22 & 27 & 72 \\
\hline D S2 Neritic & 24.6 & 23.9 & 18.3 & 27 & 17 & 47 \\
\hline D S2 Slope & 23.8 & 24.6 & 17.5 & 27 & 26 & 67 \\
\hline D S2 Oceanic & 25.0 & 25.2 & 17.8 & 27 & 29 & 52 \\
\hline N S2 Neritic & 24.2 & 24.3 & 18.2 & 27 & 30 & 52 \\
\hline N S2 Slope & 24.6 & 24.6 & 18.3 & 31 & 32 & 72 \\
\hline${ }^{\mathrm{N}} \mathrm{S} 2$ Oceanic & 25.0 & 25.0 & 17.1 & 32 & 36 & 52 \\
\hline
\end{tabular}




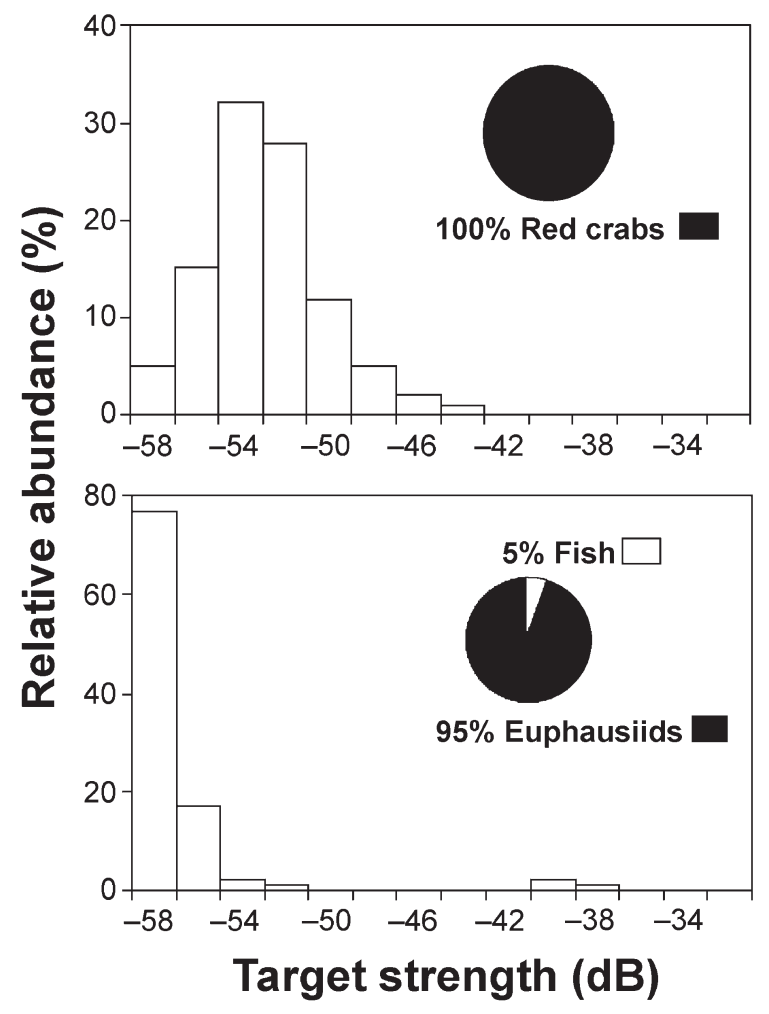

Fig. 2. Comparison of the relative frequency of target strength (dB) recorded with a Simrad EY-200 (200 kHz frequency) echosounder (histograms), and the relative abundance in samples obtained with Isaacs-Kidd midwater net trawls (pie graphs) for (A) the red crab Pleuroncodes planipes and (B) macrozooplankton (mainly euphausiids), and fish in October 1994. Upper panel is the center Zone 4, and the lower panel is the southern Zone 2 tistical analyses. During October 1994, about 62\% (median 2196 ind. ha ${ }^{-1}$ ) of the echoes corresponding to the red crab was recorded in the center area (Punta Eugenia to Punta Abreojos). Nearly similar proportions were recorded in the other 2 areas (north $18 \%$, and south $20 \%$ with medians of 492 and 189 ind. ha ${ }^{-1}$ respectively). The highest abundances of red crab aggregations were recorded nearshore in the North 3 and Center 4 transects. However, a Kruskal-Wallis nonparametric test did not show significant differences between transects ( $p>0.232, H=4.27$ ).

A set of representative echograms showing all TS ranges recorded during day and night at each transect along the central zone is shown in Fig. 3. The northern zone had long patches over the coastal shelf during the day, increasing in size and density during the night in the inshore and offshore area. In the center zone, a dense shoal with a very high abundance of Pleuroncodes planipes was observed throughout the day along the coastal shelf. In the southern zone, the smallest patches were found in the offshore area (echograms not shown).

A total of 47 Isaacs-Kidd midwater trawls were taken during the October 1994 oceanographic survey (21 day, 26 night, distributed in 3 areas: 17 north, 18 center, and 12 south). About 1450 individuals were sexed and measured. Larger animals were found in the northern area showing a nearly 1:1 sex ratio along the 3 areas. The highest abundance was observed in Punta Eugenia. A virtual absence of adults indicated that the population in the southern zone was distributed offshore (Fig. 4). The red crab abundance estimated using the depth of the thermocline was shallower in the northern area $(\sim 23 \mathrm{~m})$ than the center $(\sim 30 \mathrm{~m})$ and southern $(\sim 29 \mathrm{~m})$ areas. The change in temperature $(\Delta T)$ across the thermocline was higher in the southern area $\left(1.19\right.$ to $\left.3.32^{\circ} \mathrm{C}\right)$ than in higher latitudes $\left(>1.42^{\circ} \mathrm{C}\right)$. The mixed surface layer, defined as the layer width that is $1^{\circ} \mathrm{C}$ less than the temperature at $1 \mathrm{~m}$ depth, was thinner in neritic regions, particularly in the northern area (Table 1).

Dense red crab aggregations were recorded, assuming target strengths (TS) between -50 and -54 dB (Robinson \& Gómez-Gutiérrez 1998). Using this TS range we were able to discriminate fish and other nektonic animals such as squid and zooplankton from the red crab aggregations (Fig. 2). The rest of the TS range was neglected in the sta-

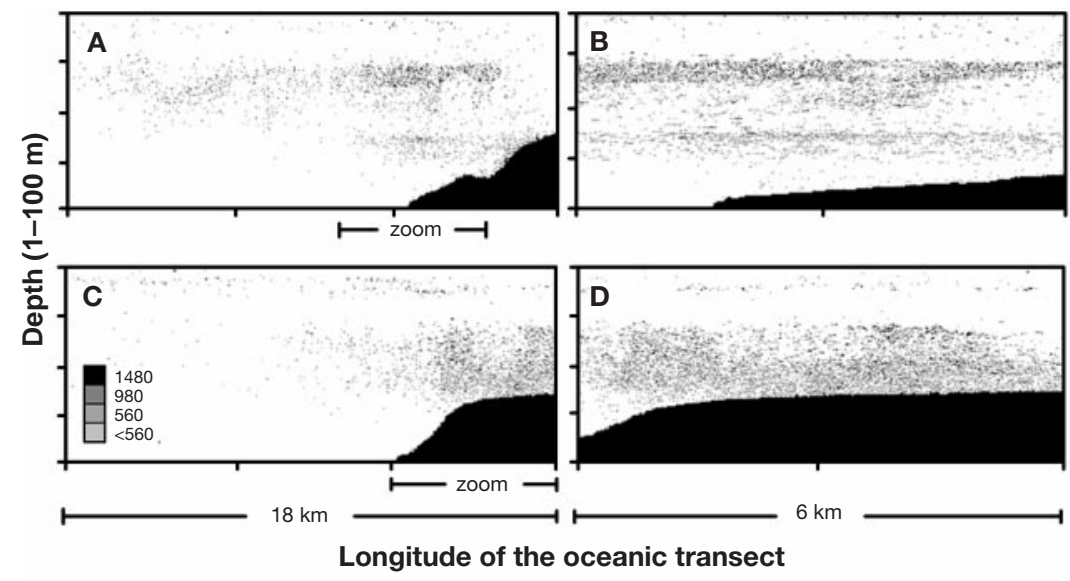

Fig. 3. Echograms recorded at center zone showing red crab aggregations near Punta Eugenia during October 1994. The black continuous layer indicates the bottom. Shades represent echo-intensity. Black points represent $1480 \mathrm{mv}$, dark gray $920 \mathrm{mv}$, gray and light gray are $560 \mathrm{mv}$ and less than $560 \mathrm{mv}$ respectively. The $920 \mathrm{mv}$ interval represents the approximate target strength used to describe the behaviour of the red crab. Echograms were recorded at (A) 22:00 h in Transect 3 located in the center zone and $(\mathrm{C})$ at $02: 30 \mathrm{~h}$ in Transect 4 also in the center zone. $(B, D)$ zooms of $(A)$ and $(C)$ showing the core of the red crab aggregations 

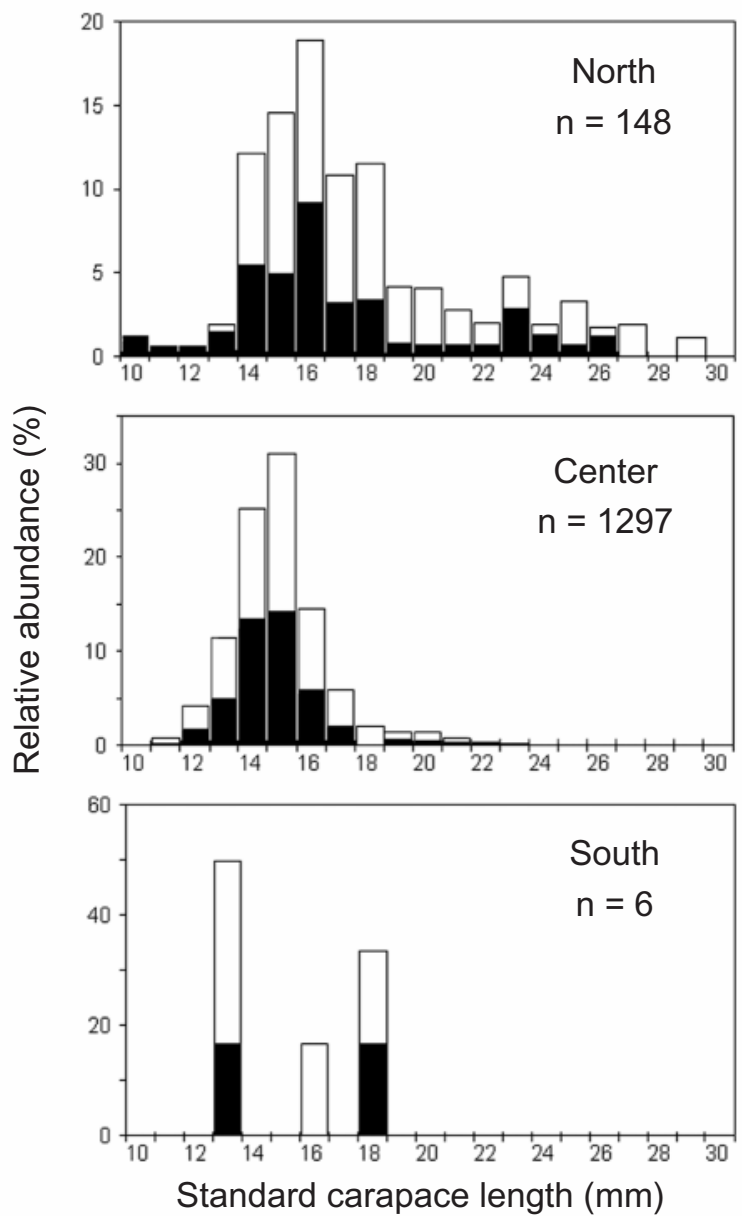

Fig. 4. Carapace length-frequency distribution for Pleuroncodes planipes sampled with the Isaacs-Kidd net at midwater depth along the west coast of Baja California during October

1994. Black bars are females and white bars are males

Isaacs-Kidd midwater net in the 0 to 50 and 50 to $100 \mathrm{~m}$ depth layers indicated no significant difference in all transects (Kruskal-Wallis test $\mathrm{p}>0.11, H=2.56$ ). The exception was the transect Center 2, where a significant difference in red crab abundance between these layers was observed ( $\mathrm{p}<0.11, H=6.56)$. These results indicate that red crab shoals perform small or virtually no vertical migration during a near $24 \mathrm{~h}$ cycle. A similar statistical analysis done to compare inshoreoffshore regions (neritic, slope, and offshore) showed no significant difference in all transects of the north and center zones, with the exception of Center 4 ( $p>$ $0.10, H=9.5)$. A significant difference in the inshoreoffshore red crab abundance was found in the line located toward the south (Center 4, Bahía Magdalena Transects 1 and 2) ( $p<0.02, H=8.0)$. Most of the red crabs detected in the last 2 transects were found offshore.

In October 1994, 172 echograms and 47 trawls were taken. The analysis of these data confirms the TS range associated with red crab to be the same as that reported by Robinson \& Gómez-Gutiérrez (1998) (-50 to $-54 \mathrm{~dB}$ ). Additionally, 649 echograms recorded in the region of Punta Eugenia (451) and Bahía Magdalena (198) during March, June, October 1995 and March and June 1996 (Table 2) were analyzed. All the echograms were obtained using the same calibrated echosounder and hydroacoustic system. For analysis, we defined positive echograms as those with more than 100 echoes in the range -50 to $-54 \mathrm{~dB}$. A value of 100 is the minimum number of echoes for HADAS to be able to estimate a reliable density. Results indicate that the percentage of positive echograms varied as a function of season and latitudinal location (Table 2). Moreover, the median abundance (ind. ha ${ }^{-1}$ ) indicated that during October 1994 and 1995, the region near Punta Eugenia showed a larger abundance than near Bahía Magdalena though a significant difference in abundance between the 2 years was observed ( $p<0.01$ ). During June 1995 and March and June 1996, red crab aggregations were more abundant in Bahía Magdalena than near Punta Eugenia. A Mann-Whitney test comparison between the medians observed for both areas indicated significant differences for all months with the exception of March 1996 (Table 2).

Table 2. Number of echograms analyzed (n) and median of the number of red crabs (ind. ha ${ }^{-1}$ ) recorded for the target strength (TS) range of -50 to $-54 \mathrm{~dB}$. All data were recorded during night (19:00 to 05:59h). $\mathrm{p}=$ probability from a Mann-Whitney test to compare medians. The percents of echograms analyzed with more than 100 echoes within the TS range are shown between parentheses

\begin{tabular}{|c|c|c|c|c|c|}
\hline \multirow[t]{2}{*}{ Month } & \multicolumn{2}{|c|}{ Center, Punta Eugenia } & \multicolumn{2}{|c|}{ South Bahía, Magdalena } & \multirow[t]{2}{*}{$\mathrm{p}$} \\
\hline & $\mathrm{n}$ & Median & $\mathrm{n}$ & Median & \\
\hline Oct 1994 & 134 & 410 (68.7) & 38 & 109 (57.9) & 0.0396 \\
\hline Mar 1995 & 124 & $858(75.8)$ & 62 & $19.8(25.8)$ & $<0.0001$ \\
\hline Jun 1995 & 126 & $4.0(16.7)$ & 60 & $66.7(41.7)$ & $<0.0001$ \\
\hline Oct 1995 & 75 & $20.0(26.7)$ & 20 & $5.4(15.0)$ & $<0.0440$ \\
\hline Mar 1996 & 56 & $1.0(17.9)$ & 32 & $9.2(9.4)$ & 0.5670 \\
\hline Jun 1996 & 70 & $42.0(32.9)$ & 24 & $1383.1(62.5)$ & $<0.0001$ \\
\hline
\end{tabular}


Discussion. Previous studies using hydroacoustics as a tool to estimate biomass and vertical migration of red crab swarms indicated daily vertical distribution (Blackburn \& Thorne 1974, Blackburn 1977, Okonski \& Martini 1978). Gómez-Gutiérrez et al. (1999) associated latitudinal changes in the sound scattering layer (SSL) with the euphausiid community structure, reporting changes in both community assemblage of euphausiids and in the morphology of the SSL in Punta Eugenia. The present work is the first extensive hydroacoustic survey of the red crab along Baja California showing clear latitudinal changes in the SSL dynamics. Our results did not show a significant difference in the circadian cycle at most transects, suggesting that red crabs remain passive in the water column at least during autumn, although sudden vertical migrations can occur at some locations (Robinson \& Gómez-Gutiérrez 1998). At a few transects, red crabs displayed active vertical migration, possibly related to biological interactions (predation avoidance or foraging). The size of pelagic red crab aggregations can be larger than previously thought, particularly inshore in the northern area, where the SSL was 7 to $10 \mathrm{~km}$ long. Even though these shoals are most likely comprised not only of red crabs, this crustacean is still an important component. Retention processes have not been comprehensively studied in this area. However, studies on the spatial distribution of planktonic species have suggested that maintenance strategies could occur (Hewitt 1981, Lavaniegos 1994). In the region of Punta Eugenia, eddies enhance high phytoplankton and zooplankton abundance which are preyed upon by the red crab population throughout the year (Walsh et al. 1977). The long-term monthly mean surface wind stress along the Pacific coast of Baja California tends to have alongshore, equatorward components during all months, implying conditions generally favorable for coastal upwelling throughout the year (Nelson 1977). Most of the seasonal variability of the surface wind stress off Baja California is in magnitude rather than in direction, weakest in the winter and strongest in the summer (Bakun \& Nelson 1977). A region of negative wind stress curl (Ekman convergence) reaches the coast of Baja California between Punta Baja and Punta Eugenia $\left(30\right.$ to $\left.28^{\circ} \mathrm{N}\right)$ throughout the year (Bakun \& Nelson 1977) (Fig. 5, shaded area). Thus, the distributions of wind stress curl in this area imply favorable conditions for the formation of fronts and convergent patches of recently up- welled water in this area. These fronts would tend to concentrate both available food and the red crab grazers within the same areas. Additionally, separate semipermanent cyclonic eddies in the regions of positive wind stress curl are evident north and south of Punta Eugenia (Reid et al. 1958, Bakun \& Nelson 1977, Hewitt 1981). Hydroacoustic results recorded in this study support the hypothesis that this negative curl wind stress promotes the nearshore accumulation, and therefore concentration, of red crabs swarms during autumn and probably winter near Punta Eugenia. Synoptic circulation patterns from the region of Punta Baja to Punta Eugenia ( 32 to $26^{\circ} \mathrm{N}$ ) during winter-spring and summer-autumn have been recently published and are summarized in Fig. 5. This information is based on the geostrophic flow estimated from 0 over $500 \mathrm{~dB}$ dynamic height anomalies published by Lynn et al. (1998) and Hayward et al. (1999). During both periods the circulation flow is parallel to the coast over the continental shelf and close to the shelf break ( $200 \mathrm{~m}$ depth) presumably promoting the concentration of the red crab aggregations close to the coast. However, the poleward flow is probably related to the 1997-1998 El Niño event. During cold years, like 1996, the poleward flow is less intense.

Latitudinal changes in the structure of the red crab population have been extensively reported, with a proposed trend towards larger animals in northern latitudes and a synchronized reproductive season (Guzmán-Vizcarra \& Aurioles-Gamboa 1992, AuriolesGamboa 1995, Guzmán-Vizcarra 1995, Gómez-Gutiérrez \& Sánchez-Ortíz 1997). This evidence suggests red crab populations are coupled to local oceanographic
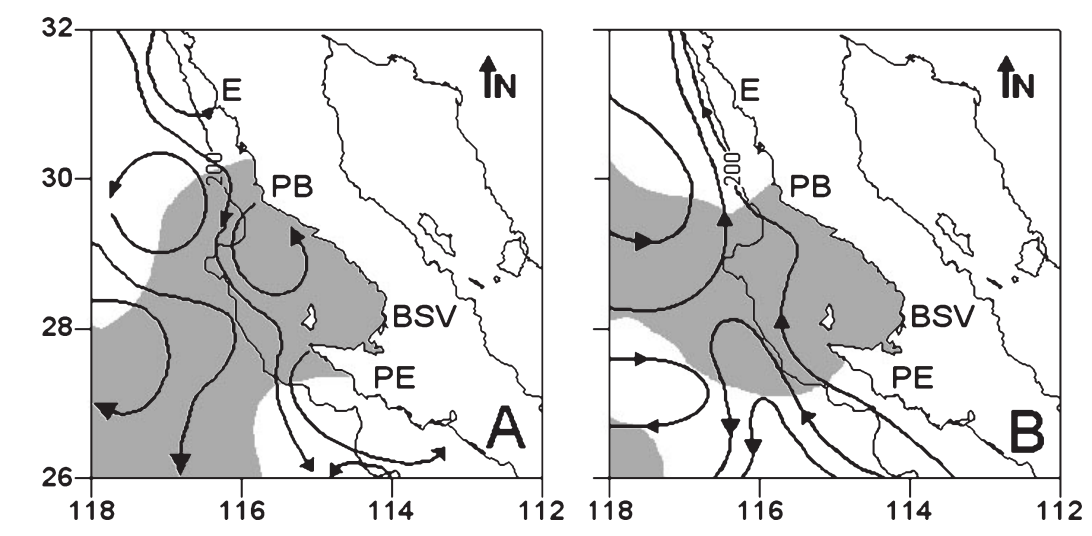

Fig. 5. Diagram of surface circulation pattern in the region of Punta Eugenia (A) during spring based on dynamic height anomaly (0 to $500 \mathrm{~dB}$ ) from Cruises 9801 and 9901 (Hayward et al. 1999) and (B) during autumn based on the dynamic height anomaly from Cruise 9709 reported by Lynn et al. (1998). The region with negative wind stress curl, which promotes convergence in the surface wind drift with corresponding frontal formation and downwelling, is shown in the shaded area (modified from Bakun \& Nelson 1977). The $200 \mathrm{~m}$ isobath is approximately the edge of the continental shelf 
dynamics. A similar situation was observed in a related species in the southern hemisphere, Pleuroncodes monodon (Milne Edwards 1837), which inhabits the narrow continental shelf off central Chile (Roa \& Tapia 1998). Adult individuals of $P$. monodon from the southern end of the population are smaller and grow faster on average than individuals from the northern end, reaching sexual maturity at smaller sizes and earlier ages (Roa \& Tapia 1998). It is evident that populations of $P$. planipes along the west coast of Baja California also have physiological differences between Punta Eugenia and Bahía Magdalena populations (see Gúzman-Vizcarra \& Aurioles-Gamboa 1992), although studies of growth and age of sexual maturation of the red crab must be done in the future to confirm this hypothesis. We believe there are also differences in migration behavior of $P$. planipes. During spring, the highest abundances of mature females are found nearshore, and a peak in the abundance of larval stages occurs during February and March. During late spring and early summer, larval drift offshore is associated with a strong Ekman transport system (GómezGutiérrez \& Sánchez-Ortíz 1997). The reproductive adult population of Bahía Magdalena (benthic and pelagic) virtually disappears from the neritic region in late summer and autumn (Aurioles-Gamboa 1992, Maeda-Martínez et al. 1993). An inshore-offshore migration of the population explains the virtual disappearance of the red crab population in Bahía Magdalena, but at Punta Eugenia (27 to $29^{\circ} \mathrm{N}$ ), very high benthic-pelagic densities of this crustacean occur nearshore during autumn. Our data indicate that higher densities occur during autumn in areas with active upwelling north of $27^{\circ} \mathrm{N}$. Thus, the red crab population of this region does not have an inshoreoffshore migration, at least during the period studied (1994 to 1996). This increase in local densities would be caused by a change in direction of the nearshore current related to the coastline. Thomas et al. (1994) reported the analysis of monthly Coastal Zone Color Scanner (CZCS) satellite data of pigment concentration along the California Current System from 1978 to 1986. Their data set indicates pigment concentrations $>1 \mathrm{mg} \mathrm{m}^{-3}$ throughout the year near Punta Eugenia, and concentrations $<1 \mathrm{mg} \mathrm{m}^{-3}$ during August to December in Bahía Magdalena with the exception of a narrow coastal core northward of this bay. The highest densities were recorded at $50 \mathrm{~m}$ depth in the water column at temperatures between 13 and $16^{\circ} \mathrm{C}$ in the north and center areas. These temperatures have been recognized as the optimum range for highest basal metabolism in the red crab (Quetin \& Childress 1976, Rizo-Díaz 1994). Thus, the saline, cold waters $<16^{\circ} \mathrm{C}$ in Punta Eugenia are favorable conditions for the red crab population because the temperature tends to de- crease locally even during the warm season (summer and autumn). Strong stratification recorded in the southern area causes low productivity and low food availability for adult red crab aggregations (temperatures recorded: 17 to $18^{\circ} \mathrm{C}$ ). Guzmán-Vizcarra (1995) and Aurioles-Gamboa (1995) reported dense red crab aggregations inside Bahía Sebastian Vizcaíno (28 to $29^{\circ} \mathrm{N}$ ) and in Bahía Ulloa (26 to $27^{\circ} \mathrm{N}$ ) during autumn and winter and near to Bahía Magdalena $\left(24^{\circ} \mathrm{N}\right)$ during summer.

The residence of dense swarms of Pleuroncodes planipes at Punta Eugenia can also be related to high particulate organic matter (POM). A higher proportion of organic matter in sediments of Bahía Sebastian Vizcaíno $\left(28\right.$ to $\left.29^{\circ} \mathrm{N}\right)$ than in the southern region of Bahía Ulloa (24 to $27^{\circ} \mathrm{N}$ ) has been reported (Chávez-López 1995). Though the red crab has been recognized as a phytoplanktivorous (Longhurst et al. 1967) and omnivorous (Arvizu et al. 1974), recent studies have reported that 60 to $100 \%$ of stomach contents of benthic adults was POM (Aurioles-Gamboa \& Pérez-Flores 1997), suggesting that this crustacean is an opportunistic species that probably uses food resources more efficiently than other animals of the region. The red crab has the ability to live at almost anoxic conditions near the seafloor of the upwelling regions (Quetin \& Childress 1976, Rizo-Díaz 1994). These dense swarms have an important ecological impact because during autumn zooplankton secondary productivity increases to maximum values inside Bahía Sebastian Vizcaíno (Lavaniegos 1995) and decreases moderately over the continental shelf from Punta Eugenia to Punta Abreojos. The red crab is thought to be an important herbivore, which may exert a size-dependent grazing stress by taking only larger diatoms (Longhurst et al. 1967), and even to be able to change the specific composition of phytoplankton, resulting in lower biomass and productivity (Walsh et al. 1977). This ability of $P$. planipes to consume large amounts of organic matter, phytoplankton, and zooplankton, and to maintain large population densities, presumably causes potential predators to remain nearshore. The consequence of inshore residence of red crab populations during autumn and probably winter is important because this crustacean is capable of ingesting from 552 to $790 \mathrm{mg}$ dry weight of phytoplankton $\mathrm{d}^{-1}$ (Longhurst et al. 1967). Smith et al. (1975) reported that red crab respiration ranged from 132 to $408 \mathrm{\mu l} \mathrm{O}_{2} \mathrm{~h}^{-1}$. Using size-frequency distribution of red crabs collected in this study from the Isaacs-Kidd midwater net, oxygen consumption $\left(\mu \mathrm{O}_{2} \mathrm{~g}^{-1} \mathrm{~h}^{-1}\right)$ per size interval was in turn estimated from wet weight expressed as grams using the equation $\mathrm{O}_{2}$ consumption $=1.95-0.31 \times$ wet weight reported by Smith et al. (1975). The respiration of the red crab population was estimated assuming (1) an oxygen consumption of 
$1.64 \mu \mathrm{O}_{2} \mathrm{~g}^{-1} \mathrm{~h}^{-1}$ (Smith et al. 1975), (2) a median red crab density during autumn 1994 calculated from acoustic surveys of 410 ind. ha ${ }^{-1}$ in the center area, and 109 ind. ha ${ }^{-1}$ in the southern area (Table 2), and (3) an average red crab body weight of $4.3 \mathrm{~g} \mathrm{ind}^{-1}$ in both regions (estimated from our Fig. 4). The respiration of the estimated population is $2.89 \times 10^{3} \mathrm{\mu l} \mathrm{O}_{2} \mathrm{~h}^{-1} \mathrm{ha}^{-1}$ for the center zone and $0.77 \times 10^{3} \mathrm{\mu l} \mathrm{O}_{2} \mathrm{~h}^{-1} \mathrm{ha}^{-1}$ for the southern zone. Therefore these red crab swarms can play an important role in oxygen consumption and trophodynamics of this coastal upwelling ecosystem during this part of the year.

Acknowledgements. Four anonymous reviewers made several comments and criticisms that greatly improved the first version of the manuscript. Thanks to all the students from the Laboratorio de Ecología de Pesquerías UNAM, to the RV 'El Puma' crew for assistance and comradeship at sea, and to Ellis Glazier and Cheryl A. Morgan, for their editorial help with the English text. This research is part of the professional thesis of Edgar Domínguez-Hernández (ICMyL-UNAM) and this research was supported by funds provided by the Dirección de Estudios de Posgrado e Investigación (DEPI 970123) and by the Consejo Nacional de Ciencia y Tecnología (CONACyT D112-904620). J.G.-G., V.A. and C.J.R. are supported by SNI fellowship and J.G.-G. is additionally supported by COFAA-IPN and a PhD CONACyT grant (122676) to study at Oregon State University.

\section{LITERATURE CITED}

Arvizu MJ, García ER, Morales IA (1974) Estudio preliminar sobre langostilla Pleuroncodes planipes Stimpson (Crustacea: Galatheidae) en la costa occidental de Baja California y Golfo de California. Secretería de industria and comercio México INP/SC 1:1-9

Aurioles-Gamboa D (1992) Inshore-offshore movements of pelagic red crabs Pleuroncodes planipes (Decapoda, Anomura, Galatheidae) off the Pacific coast of Baja California Sur, México. Crustaceana 62:71-84

Aurioles-Gamboa D (1995) Distribución y abundancia de la langostilla bentónica (Pleuroncodes planipes) en la plataforma continental de la costa oeste de Baja California. In: Aurioles-Gamboa D, Balart EF (eds) La langostilla: biología, ecología y aprovechamiento. Centro de Investigaciones Biológicas del Noroeste, S.C., La Paz, Baja California Sur, p 59-78

Aurioles-Gamboa D, Pérez-Flores R (1997) Seasonal and bathymetric changes in feeding habits of the benthic red crab Pleuroncodes planipes (Decapoda: Anomura: Galatheidae) off the Pacific coast of Baja California, Mexico. Crustaceana 70:272-287

Aurioles-Gamboa D, Castro-Gonzalez MI, Pérez-Flores R (1994) Annual mass stranding of pelagic red crabs Pleuroncodes planipes (Crustacea: Anomura: Galatheidae), in Bahía Magdalena, Baja California Sur, Mexico. Fish Bull US 92:464-470

Bakun A, Nelson CS (1977) Climatology of upwelling related processes off Baja California. Calif Coop Ocean Fish Invest Rep 19:107-127

Blackburn M (1977) Temporal changes of pelagic biomass of Pleuroncodes planipes Stimpson (Decapoda; Anomura;
Galatheidae) of Baja California, México. Crustaceana 32: 15-19

Blackburn M, Thorne RE (1974) Composition, biomass and distribution of pelagic nekton in a coastal upwelling area of Baja California, México. Tethys 6:281-290

Boyd CM (1967) Benthic and pelagic habitats of the red crabs Pleuroncodes planipes. Pacif Sci 21:394-403

Chávez-López S (1995) Los sedimentos y la geomorfología de la plataforma continental oeste de Baja California entre los paralelos $24^{\circ}$ y $29^{\circ}$ L.N. In: Aurioles-Gamboa D, Balart EF (eds) La langostilla: biología, ecología y aprovechamiento. Centro de Investigaciones Biológicas del Noroeste, S.C., La Paz, Baja California Sur, p 11-34

Craig RE, Forbes ST (1969) A sonar for fish counting. Fiskkeridir Skr Ser Havenders 15:210-219

Gómez-Gutiérrez J, Sánchez-Ortíz OC (1997) Larval drift and population structure of Pleuroncodes planipes (Simpson) (Crustacea: Galatheidae) off the southwest coast off Baja California, México. Bull Mar Sci 61:305-326

Gómez-Gutiérrez J, González-Chávez G, Robinson CJ, Arenas FV (1999) Latitudinal changes of euphausiid assemblages related to dynamics of the scattering layer along Baja California, October 1994. Sci Mar 63:79-91

Guzmán-Vizcarra E (1995) Distribución y abundancia de la fase bentónica de la langostilla Pleuroncodes planipes (Stimpson, 1860) en la costa occidental de Baja California. MSc thesis. Centro Interdisciplinario de Ciencias Marinas IPN La Paz, Baja California Sur

Guzmán-Vizcarra E, Aurioles-Gamboa D (1992) Variación invierno-verano de la distribución por tallas, sexos y densidad promedio de la langostilla (Pleuroncodes planipes Stimpson, 1860) en la costa occidental de Baja California. Proc San Diego Soc Nat Hist 21:1-8

Hayward TL, Baumgartner T, Checkley DM, Durazo R, Gaxiola-Castro G, Hyrenbach KD, Mantyla AW, Mullin MM, Murphee T, Schwing FB, Smith P, Tegner MJ (1999) The state of the California Current, 1998-1999: transition to cool-water conditions. Calif Coop Oceanic Fish Invest Rep 39:25-49

Hewitt R (1981) Eddies and speciation in the California Current. Calif Coop Oceanic Fish Invest Rep 22:96-98

Lavaniegos EB (1994) Dispersion and development patterns in larvae of Nyctiphanes simplex (Euphausiacea) in the upwelling region off Baja California. Mar Ecol Prog Ser 106:207-225

Lavaniegos EB (1995) Production of the euphausiid Nyctiphanes simplex in Vizcaíno Bay, western Baja California. J Crustac Biol 15:444-453

Lindem T, Houri HA (1988) Hydro Acoustic Data Acquisition System HADAS. Department of Physics, University of Oslo

Longhurst AR, Seibert DLR (1971) Breeding in an oceanic population of Pleuroncodes planipes (Crustacea, Galatheidae). Pac Sci 25:426-428

Longhurst AR, Lorenzen CJ, Thomas WH (1967) The role of pelagic crabs in the grazing of phytoplankton off Baja California. Ecology 48:190-200

Lynn RJ, Baumgartner T, García J, Collins CA, Hayward TL, Hyrenbach KD, Mantyla AW, Murphee T, Shankle A, Schwing FB, Sakuma KM, Tegner MJ (1998) The state of the California Current, 1997-1998: transition to El Niño conditions. Calif Coop Oceanic Fish Invest Rep 39:25-49

MacLennan D, Simmonds J (1992) Fisheries acoustics. Fish and fisheries series. Chapman and Hall, London

Maeda-Martínez AN, Reynoso-Granados T, Solís-Marín F, Lejia-Tristán A, Aurioles-Gamboa D, Salinas-Zavala C, 
Lluch-Cota D, Ormat-Castro P, Felix-Pico E (1993) A model to explain the formation of catarina scallop, Argopecten circularis (Sowerby, 1835) beds in Magdalena Bay, México. Aquacult Fish Mag 24:399-415

Nelson CS (1977) Wind stress and wind stress curl over the California Current. US Dep Commer. NOAA Tech Rep NMFS, SSRF-714:1-87

Okonski SL, Martini LW (1978) Informe técnico sobre las experiencias précticas de pesca de la langostilla en Bahía Magdalena, Baja California, utilizando arrastrero de productos pesqueros mexicanos A-26-A. Programa de investigación y desarrollo de pesquerías en México PNUD/ FAO, Departamento de Pesca, Cuidad de Mexico

Quetin LB, Childress JJ (1976) Respiratory adaptations of Pleuroncodes planipes to its environment off Baja California. Mar Biol 38:327-334

Reid JL, Roden GI, Wyllie JG (1958) Studies of the California Current system. Calif Coop Oceanic Fish Invest Rep 1: 27-56

Rizo-Díaz BLE (1994) Metabolismo rutinario de la langostilla Pleuroncodes planipes en relación a la distribución y abundancia en la costa occidental de Baja California Sur. MSc thesis, Centro Interdisciplinario de Ciencias Marinas IPN, La Paz, Baja California Sur

Roa R, Tapia F (1998) Spatial differences in growth and sexual

Editorial responsibility: Otto Kinne (Editor),

Oldendorf/Luhe, Germany maturity between branches of a large population of the squat lobster Pleuroncodes monodon. Mar Ecol Prog Ser 167:185-196

Robinson CM, Gómez-Gutiérrez J, Arenas FV (1995) Diel vertical and offshore-inshore movements of anchovies in an upwelling area off Baja California. J Fish Biol 47:877-892

Robinson CM, Gómez-Gutiérrez J (1998) The red-crab bloom of the west coast of Baja California, México. J Plankton Res 20:2009-2016

Smith KL Jr, Harrison GT, Rowe GT, Clifford CH (1975) Respiration and chemical composition of Pleuroncodes planipes (Decapoda: Galatheidae): energetic significance in an upwelling system. J Fish Res Board Can 32:1607-1612

Smith PE (1985) A case history of an anti-Niño transition plankton and nekton distribution and abundances. In: Wooster WS, David LF (eds) El Niño North: Niño effects in the eastern subarctic Pacific Ocean. Washington Sea Grant, Seatle, p 121-142

Thomas AC, Huang F, Strub PT, James J (1994) Comparison of seasonal and interannual variability of phytoplankton pigment concentration in the Peru and California Current System. J Geophys Res 99(C4):7355-7370

Walsh JJ, Whitledge TE, Kelley JC, Huntsman SA, Pillsbury RD (1977) Further transition states of the Baja California upwelling ecosystem. Limnol Oceanogr 22:264-280

Submitted: March 17, 2000; Accepted: September 14, 2000

Proofs received from author(s): November 6, 2000 